\title{
THE POLITICAL ANNEXATION OF THE SPORTS HERO IN CONTEMPORARY ROMANIA. THE CASE OF SIMONA HALEP
}

\author{
Vasile-Teodor BURNAR ${ }^{1}$ \\ DOI: 10.35782/JCPP.2021.1.02
}

\begin{abstract}
The present article aims to highlight the ways in which the sports hero in Romania is "annexed", ie used and instrumentalized by the political power, represented by public institutions, political parties and / or politicians. The case study analyzes the ceremonies and awards bestowed upon the tennis player Simona Halep, the most prominent sports figure of Romania in the past decade, by a number of local authorities in the country (Busteni, Constanța, Călărași, Bucharest, Clij) and by the Romanian Presidency, from late 2013 to the present day. We scrutinize the reasons behind such feats of public homage and the media coverage it entailed, while also trying to explain why sport, and tennis in particular, is courted assiduously by politicians in the country and what this reveals about the standing of the sports hero in Romanian society and political legitimization strategies. We also explore the reasons why apparently similar political strategies of gaining political kudos through association with a sport hero work brilliantly for one Romanian politician and dramatically backfire for another. Last but not least, we take a look at the way the sports hero was instrumentalized during the COVID-19 pandemic.
\end{abstract}

Keywords: political annexation, sports hero, sports and politics, Simona Halep, COVID-19

\section{Preamble and Objectives}

This article aims to analyze the ways in which the sports hero in contemporary Romania is "annexed" and used by the political power, using as a case study the public honors bestowed upon tennis player Simona Halep, who in the past 6 years has become one of the most influential Romanians from outside the political sphere, gaining, by virtue of the performances achieved in her sport, wide social recognition and popular sympathy (Express Press, 2015). Since this kind of recognition of the great champions

\footnotetext{
${ }^{1} \mathrm{PhD}$ student, Faculty of History, University of Bucharest, e-mail: vasile.teodor.burnar@drd.unibuc.ro
} 
in Romanian sport has become customary, and their annexation by the political factor along with other interested parties is a recurring reality (GSP, 2011; HotNews, 2018b), we intend to analyze the way in which a series of public institutions in Romania (the town halls of Buşteni, Constanța, Călăraşi, Bucharest; the city of Cluj - through the Cluj County Council, but especially through the mayor Emil Boc; the Romanian Presidency) put it in practice and legitimized themselves overtly, by associating with Simona Halep.

The general objective of this article is to review the ways in which the sports hero (Simona Halep) is publicly mythologized and glorified. In this sense, we will define the sports hero, then we will review a series of public festivities that had as a protagonist the tennis player from Constanța, focusing on the most publicized of them. Last but not least, we aim to analyze the significance of the athlete in the hierarchy of heroes accepted by the public, and the analysis of the place that the sports hero holds in the legitimizations of the political factor.

Our analysis seeks to answer the following questions: a) What are the ways and strategies by which Romanian political institutions and politicians exploit / annex a sports celebrity / a sports hero? Can it be compared with other cases, from other sports or other geographical and cultural areas?; b) What is the concrete way in which the athlete is honored as a public hero and what are the image benefits that political forums and politicians want to obtain from that homage?; c) what was the reaction of the public opinion and the mass media in Romania towards the instances in which the sportswoman Simona Halep was the protagonist of an "annexation" (or attempt of) by politicians? Was there a double standard in evaluating these "seizures"?; d) by whom does a sports hero nowadays accept to be "annexed", and why?

\section{Heroism and Heroes}

"The human inclination to commemorate heroes" and to celebrate their achievements "seems to be a universal feature of human culture" (Becker \& Eagly, 2004, p. 163), which spans history: from oral traditions in Antiquity and medieval poems, to contemporary society, where heroes are honored "not only in literature, but also in film, television and journalism" (ibid.). Hook (1945) says that the hero is as old as history, while Fishwick (1975) sees in heroes «the mirrors of time»: "Every hero mirrors the time and place where he lives. He must reflect the most intimate hopes and beliefs in a public way". In general, Becker and Eagly (2004, p. 163) note that "heroes and heroism are defined in terms of courage and risk of one's life as well as noble purpose". A common denominator of the various theoretical orientations regarding heroism seems to be its inclusion in the broader category of prosocial or helpful behaviors (ibid., p. 164), "accepting the risk to one's own life being the one that (...) transforms prosocial behavior into heroism".

\section{Sport as a repository of moral values}

Sports heroes are central to modern sport. For Holt et al. (cited in Lines, 2001), "sport without a hero is like Hamlet without a Prince". The question is whether sport "can revitalize the moral spirit, without which the community risks becoming an empty 
abstraction" (Smart, 2005, p. 4). To paraphrase Inglis (cited in Smart, 2005), sport used to be a repository of ideas «that were central to our morality» (ibid., p. 5). The special moral quality attributed to sport and to its practitioners, amateurs or professionals, would therefore be the bridge between heroism lato sensu and sports heroism. Sport "has been credited with the ability to nurture "the natural impulses of generosity, elation, heroism, grace, [and] decorum" (Inglis, cited in Smart, 2005).

For some authors, however, the influences and (media, financial) pressures to which sport and athletes were increasingly subjected during the twentieth century "eroded, if not completely undermined the moral value of sport and the prospect of «authentic» sporting heroism" (Hoch, cited in Smart, 2005). It is obvious that heroism has been substantially changed by the rigors and boom of contemporary media.

Without sharing the finality of the classic, martial hero - if we do not consider sport a surrogate of war, as Orwell (2000) proposed, the sports hero serves a similar function (Norwood, 1982, p. 12), heroes and sports legends being held in high esteem by contemporary society and press (ibid., p. 13).

\section{The modern sports hero}

According to Barney and Barney (1989), athletes become heroes because of their consistent and remarkable long-term performance, as well as because of their morality, proven social responsibility, and intellectual abilities. Smith (1973) says that modern sports heroes have special physical abilities, maintain a standard of excellence year after year, overcome obstacles, and display individual flair or charisma. Modern sports heroes, notes Wenner,

are models of athletic competence and of social values who are admired for their outstanding and skillful sporting performance, their courage, expertise, perseverance, assertiveness, generosity, social ideals, dependability, honesty and character. (Lawrence A. (ed.), 1998, p. 138).

Writing in Dilema Veche magazine, Coman (2010) distinguishes between stars, celebrities and heroes. The first category is allegedly a meteoric one and maintained by the media, the second is recommended by artistic, sporting, economic performances etc., which "enjoy public recognition and intense media coverage". Heroes, writes Coman, "remain in the collective consciousness for a remarkable deed, usually one with a larger purpose" marking the history of a community, which would also extend to sporting achievements. It remains to be seen whether Simona Halep is just a transient national hero (Dumitriu, 2018, p. 30) - it is certain that she enjoys, at this moment, the status of sports hero and a lasting celebrity.

\section{The politics-sports relationship. The political annexation of the sports hero}

It has been argued (Hoberman, 1977, p. 82) that, based on historical evidence, "sport is not an ideologically neutral entity". If we looked at it as a mere physical activity, 
exclusively utilitarian, it would be "really harmless". However, the appropriation of sport (and especially of its heroes) by "ideological observers of all kinds: political figures, writers, sociologists" etc. invalidates the thesis of neutrality. Sport, therefore, "gives rise to meanings, including ideological" appropriation, "only when an observer thinks of it" (ibid.). Moreover, sport has been transformed, countless times throughout history, into a policy instrument, "being appropriated by observers with ideological interests (Paddick, 1984) and integrated into a political Weltanschauung" (Hoberman, 1977, p. 83).

As sport is a popular leisure activity and has a "liquid quality" (Edwards, 1973, cited in Paddick, 1984, p. 61), which makes it "ideologically innocent" (Hoberman, 1977, p. 80), it is common for politicians to use sports and sports figures as a resource, for a variety of political purposes. Sport provides politically useful resources, and modern sport in particular has been "rarely free from political influence" (Horne et al., 1999, cited in Lin et al., 2008).

Like religion and show business, sports offer the politician association with something non-political that large numbers of people are attracted to. Not only do politicians use the rhetoric of sports for political purposes, they also express their interest in sports to dramatize their commonality. Candidates campaigning for office attend sporting events, mention the local team, and seek the endorsement of famous athletes. Endorsement-seeking illustrates how the politics seeks out popular culture. The endorsement of a famous athlete somehow gives the aspiring politician a kind of popular status and humanity he might not enjoy otherwise. The athlete is the embodiment of both material and moral success on the playing-field, and the politician seems to think that with the association some of the heroic magic might rub off. And this is nothing new: both $\mathrm{Al}$ Smith and Herbert Hoover sought the endorsement of Babe Ruth in 1928! (Combs, 1984, p. 67)

In the last century, the danger of exploiting sport for commercial and political purposes has increased (Pedersen, 2013), as the resonance of the phenomenon and of sports heroes in society "exploded". The Nazi Reich, fascist Italy and Peronist Argentina (Rein, 1998) each used sport for ideological purposes, while communist countries such as the GDR and the USSR (Riordan, 1977 cited in Paddick, 1984, p. 59) "have invested heavily in sports, often to support nation-building and to use international success, especially Olympic success, to demonstrate the superiority of communism over capitalism" (Houlihan, 2007). However, not only authoritarian systems resort to sport, but also politically stable and economically advanced states: the opportunity to strengthen national identity through sports success and to do diplomacy and country marketing via sport, as a soft power resource, is far too tempting to ignore (ibid., pp. 3472-3476). It should also be noted that in the scheme proposed by American sociologist Orrin E. Klapp, which explains the appearance of a popular hero, public recognition and formal honors represent the second stage (Klapp, 1949), out of a series of five that lead to the "hero cult". 
For the purposes of this analysis, as the terminology related to the instrumentalization of sport and sports heroes is diverse, the terms "annexation", "exploitation", "appropriation", "instrumentalization" will be used alternately, but always with the same meaning, that of using sport and sports heroes for an ideological purpose, to advance a political message or to improve the image of the politician / entity associated with the sports hero in order to "annex" his / her celebrity.

An object of the political annexation we analyze, celebrity has become a defining feature of our media society. Ubiquitous in the mainstream media and the tabloid press, in advertising and activism (Driessens, 2013, p. 641), it has profoundly affected many areas, especially politics, as "celebrity has become a valuable resource to use in power struggles" (ibid., pp. 641-42). Celebrity status gives those who enjoy it discursive power and a voice that cannot be ignored (Marshall, 1997, cited in Driessens, 2013, p. 642) and is supposed to function as a general mark of success (Bell, 2010, cited in Driessens, 2013, p. 642). Celebrity culture, notes Cashmore (2006, p. 6), "affects (...) not just passionate fans, but entire populations". Indeed, the social and cultural impact of celebrity is obvious - what has been conceptualized as celebritization (Driessens, 2013, p. 643). One interpretation of this phenomenon is that it denotes the versatility of celebrities within media and entertainment (Lewis, 2010, cited in Driessens, 2013) and their "migration" to areas not traditionally associated with fame. A celebrity who supports a politician or even becomes one is a common example.

The link between the media, the entertainment industry (to which sport can be ascribed) and politics has generated the phenomenon known as "celebrity politics" (Agyepong, 2017). It has its historical origins in the United States, where the Kennedy era and Ronald Reagan's election were seen as the point of convergence between "celebrity production lines and politics" (Turner, 2004, p. 18). It is noteworthy that the literature on politicians and other decision-makers who use celebrities, either trying to become celebrities themselves or using celebrities to legitimize their policies, is limited compared to those dealing with the involvement of celebrities in politics.

In a typology developed by Marsh, 't Hart and Karen Tindall, the authors supplement the existing framework with a new category, that of the politician who uses others' celebrity, described as ,office holder who uses specific celebrities and others' fame to endorse their own candidature, party or policies" (Marsh et al., 2010, p. 327). The typology of celebrity politics proposed by Marsh et al. also includes "celebrity advocate", "celebrity activist / endorser", "celebrity politician" and "politician celebrity" (ibid.). It is in the novel category of this typology that we will include the politicians who "annexed" (or tried to annex) the celebrity and the success of the sports hero Simona Halep, in cases that we will analyze.

The persuasive effect of famous activists and supporters seems to be more pronounced when certain conditions are met. 't Hart and Tindall (2009, cited in Marsh et al., 2010) argue that the political and charitable activities of celebrities will be seen as more significant and successful the more the initial source of their fame is based on merit, the greater the social prestige of the cultural field in which the celebrity gained fame; the longer the fame; and the wider (geographically and numerically) and more open (relative to social classes and cultural groups) is the extent of fame. All the boxes seem to be 
ticked in the case of Simona Halep, one of the most popular contemporary Romanian athletes (DigisportRo, 2019).

\section{The political annexation of sports heroes around the world}

The phenomenon of the annexation of sport by politics is not, as we mentioned at the beginning, by far a Romanian one. Congratulating, nominating and honoring sports heroes with distinctions or special ceremonies are practiced all over the world.

For example, on the occasion of the World Cup held in Russia in 2018, the controversial Chechen leader Ramzan Kadyrov granted the honorary citizenship of the country to the Egyptian national star, Mohamed Salah, taking advantage of the fact that the "Pharaohs" set camp in the Republic. According to The Guardian (2018), dictator Kadyrov vehemently denied using Salah's presence in Grozny to generate positive publicity. Even so, the quoted source notes, Kadyrov made sure that a series of photos of him with Salah were made public.

Other footballers have also become honorary citizens of some localities - among them the Portuguese Luis Figo (The Portugal News, n.d.), the Argentine Diego Maradona (La Stampa, 2017) or the German Philipp Lahm (BeSoccer, 2019).

Tennis too attracts public honors. In August 2014, the most successful player in Bulgaria, Grigor Dimitrov, received the title of honorary citizen of the city of Varna, with unanimous votes (Novinite 2014). That same year, the famous tennis player Rafael Nadal, born on the Spanish island of Mallorca, received the title of "adopted son" of Madrid, the highest distinction of the city, from the mayor Ana Botella (Dawn, 2014). Another Iberian tennis player, Carlos Moya, was honored in 2004 with the honorary citizenship of the Croatian city of Umag, receiving a special medal from Croatian President Stjepan Mesić (Croatia Open Tournament History, n.d.).

In women's tennis, the Hungarian player Timea Babos was among the eight athletes, artists and scientists rewarded by the Budapest Municipal Assembly in 2018 because "through their activities, served the development of Budapest and the growth of its reputation" (Babos, 2018). The award consisted not only of honorary citizenship, but also of a financial incentive (ibid.). The first Japanese to become a world leader in the WTA circuit, Naomi Osaka, was congratulated in January 2019 by Japanese Prime Minister Shinzo Abe, who thanked her for her victory at the US Open, purportedly giving Japan energy and excitement in difficult times (The Guardian, 2018). And the success of Halep's opponent in the final of Roland Garros 2017, the Latvian Jelena Ostapenko, was publicly exploited, with the youngster becoming the star of a video presentation of her hometown, Riga (Focus on Travel News, 2018).

It should be noted, however, that politicians do not always "blindly" consent to the annexation of a popular sports figure. This was the case of the Polish tennis player Agnieszka Radwanska, who was nominated in 2019 for the honorary citizenship of Krakow, her hometown, but did not receive the distinction. "Honorary citizenship (...) is not a medal for sports achievements, but for achievements for the city, for the 
14 The political annexation of the sports hero in contemporary Romania - Simona Halep

development of a certain field in the city. Something we haven't seen yet", explained a public official, Rafa Komarewicz (Afaae, 2019).

\section{Politics and tennis on harmonica tones}

In the recent history of Romania, the use of sports heroes by the political factor is a common practice: because sport enjoys a unique social impact, an important sporting performance is rarely ignored by politicians. The famous party at the Golden Blitz restaurant (ProSport, 2018a), featuring, in April 2006, the then president of Romania, Traian Băsescu, who came to congratulate the footballers of Steaua Bucharest for qualifying for the UEFA Cup semifinals, is a classic case of "annexation" of the sport.

As we have shown, the association with sport has political utility. Additionally, "as sports figures become popular embodiments of heroic success, their celebrity status can become a resource for successful political recruitment" (Combs, 1984, p. 68). For example, in Liberia, former footballing great George Weah won the chair of president in 2017 largely due to his status as a national hero (IICRR, 2018). However, "the transfer of magic is not guaranteed": in 1976, the US presidential candidate, Gerald Ford, was supported by a plethora of athletes, which, however, did not bring him the success he craved (Combs, 1984, p. 67). The National Union for Romania's Progress party (UNPR) built its communication campaign in the 2019 European elections on the sporting successes of two former glories, Ilie Năstase (tennis) and Anghel Iordănescu (football), who opened the electoral list (Ştiripesurse, 2019). However, the strategy of annexing the two big names in sports failed miserably (GSP, 2019b).

Simona Halep's star has attracted, through its growing brilliance, the Romanian political parties and Romanian politicians of recent years. One of Simona Halep's first political "annexations" took place in December 2013 (GSP, 2014a; Actualitatea Prahoveană, 2014), after the 23-year-old athlete at the time, star of Romanian tennis, had a remarkable year in the W'TA circuit, winning no less than six tournaments (GSP, 2014b). To the surprise of some, the one who decided to publicly honor Halep was not the mayor of Constanța, her hometown, Radu Mazăre, who had publicly expressed his reservations about the value of tennis (Libertatea, 2018), but, the mayor of the mountain town of Buşteni, Emanoil Savin. He granted the young sportswoman the title of honorary citizen of the locality, a distinction to which a 500 -square-meter plot of land was later added (Jurnalul Prahovean, 2014b), for which Halep signed the paperwork two months later.

"Buşteni will become the capital of Romanian tourism in the future and it seems natural to me that all the great Romanian personalities will have a house in this resort, where they will retire in their old age, a kind of neighborhood of champions. On the other hand, Bussteni supports the sporting performance and it seems natural to me to reward [Halep] properly", mayor Savin defended his gesture, according to Adevărul (2013).

An article published in February 2014 on an online information platform by Buşteni City Hall noted (IloveBusteni, 2014) that "Simona Halep was welcomed today, according to tradition, with bread and salt and huge bouquets of flowers by the mayor of Buşteni, Emanoil Savin, at the Buşteni City Hall". The same piece of news pointed 
out that the ceremony was attended by the future neighbors of Halep, the judoka Alina Dumitru, gold medalist at the Olympic Games in 2008, and the fighter Ionuț Iftimoaie, in turn rewarded by Emanoil Savin's mayor's office in previous years (Adevărul, 2014), as a part of a euphemistically called "tradition" - in fact a well-developed tourism marketing strategy by the officials of the institution from Buşteni, meant to increase the visibility of the town (Adevărul, 2013) and presumably to promote the mayor. No less than 50 personalities from various fields had been rewarded at that time by the Busteni City Hall and the mayor Emanoil Savin with the title of honorary citizen of the locality, the mayor talking about the creation of a "Champions Quarter" in Buşteni. The article went on to note that "Simona was dealt a big surprise, prepared especially for her by Emanoil Savin, namely two huge cakes, one in the form of a tennis racket and the other representing the trophy won in Doha" (IloveBusteni, 2014. Please note that the underlinings in both quoted paragraphs belong to us and want to highlight the self-laudatory, sometimes hyperbolic rhetoric practiced by Busteni City Hall and Emanoil Savin at the award ceremony in honor of Simona Halep).

More interesting than the honors themselves - in fact, typical and practiced all around the world for exceptional achievements in a field of activity - was the ceremony staged for Halep. A filming of the event (Ziua de Constanta, 2014) shows how, at the entrance to the Bussteni City Hall, the sportswoman is greeted by Mayor Savin with the two festive cakes. The score is provided by a harmonica player hired by the town hall, who performs the couplet:

\author{
With respect and value \\ The bonorary citizen \\ Made her life beautiful \\ The tennis player from Constanta! \\ She has no worries or care \\ World number 7 , aye, \\ And I'll win game after game, \\ 'cur I also wanna win a Grand Slam!
}

The association of Buşteni with Simona Halep, who announced her intention to build a house in the city (Libertatea, 2014), was just beginning to take shape. In the summer of the same year, after the final played at Roland Garros, the new honorary citizen was congratulated by the local mountain rescuers. "The Princess of the Carpathians", as she was nicknamed ad hoc by the local press (Jurnal Prahovean, 2014a), was honored by the authorities with a huge banner raised over 2300 meters high, under a symbolic place, the Monument of Heroes - the Cross of Caraiman. On the banner, an onlooker could read, in huge letters, "Thank you Simona Halep!".

In the summer of 2017, right after surprisingly losing the final at Roland Garros to Jelena Ostapenko, Halep returned to Buşteni where, according to press, she was received with honors (Fanatik, 2017) by local officials represented by Mayor Irinel Ghiță and Deputy Mayor Nae Savel. It should be noted that the former mayor, 
Emanoil Savin, who had opened the series of honors towards Simona Halep, had meanwhile become a senator.

In October 2017, a message from the parliamentarian for the newly crowned world leader received publicity. "Unlike others, Emanoil Savin knows a champion when he sees one" an article in the national press stated (Republika News, 2017). "He greeted most of Romania's great athletes in Buşteni, when he was mayor of the Prahova resort. One of the biggest, obviously, is Simona Halep", the source noted.

In December 2017, just two months after securing the world number 1 position, a premiere in Romanian women's tennis, Halep received, also from Buşteni, a rare accolade, being honored with an occasional postage stamp, valid on the spot for only one day, and also with a postcard. The initiative belonged to the same Savin, this being a joint venture by the Bussteni City Hall, the Bartoc Cultural Foundation, the Bucharest Philatelists' Association and the national postal services operator, Poșta Română (Observatorul Prahovean, 2017). The stamp contained the inscription "WORLD NUMBER 1 IN THE 2017 WTA RANKING", and the postcard showed Simona Halep next to the globe. The reverse of the illustration marked the connection between Buşteni and Halep, emphasizing that the latter, "HONORARY CITIZEN OF BUŞTENI, BECAME ON OCTOBER 7, 2017, IN BEIJING, THE LEADER OF WORLD TENNIS", with the text being superposed on an image of the mountain city. 500 copies of the postcard were put on general sale.

Buşteni City Hall's desire to "capitalize" on Simona Halep's success was also evident in the summer of 2018 , less than a month after her triumph at Roland Garros. Then, the mayor's office officials issued and released for circulation a new limited series of 400 postcards, inscribed with the face of Simona Halep and the Roland Garros trophy, a gesture occasioned by the Bussteni City Days. The postcard portraying Halep served, inter alia, "to mark the 110th anniversary of the first documentary attestation of Buşteni". Observers noted that the tribute was normal, as another world number one in Romanian tennis, former glory Ilie Năstase, had also enjoyed it (ProSport, 2018b).

The road opened by Buşteni was followed by other public institutions and officials from Romania. In June 2014, on the very day when Halep climbed to 5th place in the world, the local councilors from Constanța, together with the mayor Radu Mazăre, finally offered her in absentia the distinction of honorary citizen and the key of the city, as well as a land of about 500 square meters in the locality (Digi24, 2014). "Of course, there are some who will say that they proposed to make her an honorary citizen a few months ago and I said that she must grow. I see it stimulated her and she grew very fast. Once again, congratulations! ", mayor Mazăre was quoted as saying. A local councilor, Stelian Gima, noted that Halep brings international notoriety to Constanța, likening its reputation to that of the well-known summer resort of Mamaia (ibid.).

\section{"Many in Călăraşi wonder why Halep is an honorary citizen"}

One of the cases of political annexation of Simona Halep that raised the most eyebrows took place in Călăraşi, on November 28th, 2018 (Observator de Călăraşi, 2018). 
Coming after an exceptional year, the leader of the WTA hierarchy accepted the invitation of the local officials, led by mayor Daniel Ştefan Drăgulin, to pay them a visit to receive the title of honorary citizen of Călăraşi municipality. It is interesting to note that the invitation was issued through the Călăraşi Branch of the Romanian Aromanian Community, which also organized a special event in her honor. According to Romanian media (Fanatik, 2018), about 700 Aromanians lived in Călăraşi at the time. Faced with doubters of its honesty, the organization was quick to motivate its approach: "The grandparents from the father's side, Halep Stere and Zoica, grandparents Halep Nicolae and Sirma, as well as grandparents from the mother's side, Pufleanu Dumitru and Chiraţa, and grandparents Pufleanu Pana, emigrated to Cadrilater in 1932, locating in Rahman-Asiclar commune, Călăraşi county, passed through Călăraşi on arrival, frequented Călăraşi municipality through their preoccupations and so connected with Călăraşi " (Jurnalul de Calarasi, 2018).

On a blizzard, Halep arrived in Călăraşi, where the workers fought with the snow all morning to pave way. "There has been no such mobilization since the elections", was the extremely expressive comment of one of the workers (Sport.ro, 2018). The festive agenda included a visit to the office of the mayor Drăgulin, the presence at a show honoring the champion, the handing over of the title of honorary citizen by the mayor, press statements and an autograph session.

Of interest for the present analysis is the way in which the initiators of the event justified their gesture and exploited the moment in the media. Thus, Mayor Drăgulin declared: "Why Simona Halep? Because she is Romanian. Why Simona Halep? Because Romania lacks models. She is a model of work, ambition, perseverance, effort. All this is embodied in this golden lump that Romania has and which is called Simona Halep. We are a small community, around 68,000 inhabitants, who I am convinced are following Simona. Why Simona Halep? Because she is ours and, although she does not have a Călăraşi ID, we adopted her, and I am honored that I am her contemporary". The same Drăgulin promised a tennis complex in Călăraşi that was to be named after the tennis player (Ediția.ro, 2018). Taking advantage of Halep's presence in Călăraşi, the mayor then seemed to validate his own public policies (Marsh, 2010, p. 327), stating that "Today is a time when, slowly, slowly, Călăraşi sits (sic!) on the map of Romania as a city where things are done, step by step, so that the citizens of this city feel ever closer to home" (Observator de Călăraşi, 2018).

This time too, the media highlighted the ritual staged for Simona Halep: the tennis player " was greeted with bread and salt" by two children in traditional Romanian costumes (Actualitatea de Călăraşi, 2018) and was received in the office of the mayor Daniel Ştefan Drăgulin, signing in the book of honor and also on a miniature flag" (Ziua de Constanța, 2018).

Not all the people of Călăraşi welcomed the invitation extended to Halep, however. In a video dedicated to the event, Pro TV news remarked, with transparent irony, that "in Călăraşi there is no tennis court and many people in the city wonder why Halep is an honorary citizen", given that "she never had any connection with this city" (Sport.ro, 2014). In an article titled "Tennis player from Constanța, Simona Halep, will receive the title of honorary Călăraşi. This is why ... “, the journalist Marian Pîrloagă, from the 
publication Atitudinea din Călăraşi, ironically commented on the whole approach, suggesting that it represented a sample of political opportunism (Atitudinea din Călăraşi, 2018).

The most acid comment regarding the distinction given to Halep in Călăraşi came, however, from the local journal Realitatea din Călăraşi, in an article entitled, suggestively, "Sula ${ }^{1}$... the Prefecture... Drăgulin... the Press Office and Simona Halep!", that catalogued the event as a "masquerade" with the "sole purpose" of promoting the mayor:

We believe that the great champion Simona Halep has nothing to do with the city of Călăraşi. Our newspaper refuses to take part in this masquerade with the sole purpose (...) to promote the image of Daniel Ştefan Drăgulin, on the advice of some councilors paid with public money, who have no idea what world they live in. (Realitatea din Călăraşi, 2018)

\section{A successful annexation: Emil Boc}

Another Romanian politician and mayor, the former prime minister Emil Boc, currently the mayor of Cluj-Napoca, had a clearly superior media coverage regarding the association with Simona Halep. Over time, Boc, a regular of appearances next to athletes and singers (Antena 3, 2011), stood out as a supporter of the Fed Cup (women's tennis) team of Romania - which he hosted in Cluj in 2016, twice in 2018 (when he met Simona Halep at the airport), and in 2020 respectively. Moreover, in 2018, Boc was warmly embraced by Simona Halep at the end of the match with Patty Schnyder, a gesture that made the rounds around Romania. "Surely no mayor in the world will have this honor," Boc said at the time, according to Fanatik (2018).

In February 2019, when Romania played again with the Czech Republic, this time away, in the quarterfinals of the Fed Cup, Mayor Boc made his way abroad, where he was leader of the fans and drummer-in-chief, being noticed and praised, for his efforts, by Halep (Pal, 2019). It is noteworthy that the group of supporters from Transylvania displayed a banner in Ostrava on which was written "Cluj-Napoca supports the Romanian team" (Andrei, 2019).

Two months later, in the Fed Cup semi-final against France, played in Rouen, Emil Boc "relapsed", stepping once again in the spotlight as leader of the Romanian fans who went to the Hexagon, with the mayor being singled out for praise by the non-playing captain of Romania, Florin Segărceanu (Monitorul, 2019a). According to Gazeta Sporturilor, which interviewed him on that occasion, the "ultras" Boc "was a one-man show at the confrontation France - Romania 3-2, from the Fed Cup semifinals. The mayor led the supporters in the stands, acting like a real supporter during the two days of the competition" (Dinu, 2019).

The frequent appearances at Romania's tennis matches and his friendship with Simona Halep seem to have benefited Emil Boc and Cluj, the mayor being labeled by the press

\footnotetext{
${ }^{1}$ Expletive with sexual connotations, in Romanian.
} 
as "a big fan of tennis", which allowed him to talk about the possibility of Cluj hosting a WTA tournament. The move would further increase the prestige of the Transylvanian city, which in recent years has stood out through the electronic music festival UNTOLD (Prodan, 2015). In his turn, the businessman Ion Tiriac, a close friend of Halep, confirmed that he will discuss with Emil Boc on this topic (GSP, 2019a). Moreover, the press speculated that Boc's presence on Romania's trips was part of a communication strategy developed to lobby a future indoor tournament in Cluj, which was to be organized from 2020 (Sport.ro, 2019; Media9, 2019a). Some local journalists were not at all convinced of the sudden passion for tennis of Boc and his men. Commenting on the presence of a real squadron from Cluj Municipality at the match in Rouen, a publication sarcastically shouted, referring to "Simona Halep's directors' gallery": "Come on Romania! We are locking the City Hall!" (Media9, 2019b).

In June 2019, Halep returned to Cluj, with the city hosting (with the direct support of the Cluj County Council), for the second year in a row, Sports Festival (Ziare.com, 2019), where the tennis player starred in an exhibition. Again, the good relations between Emil Boc and Simona Halep came to light: during the exhibition, Halep invited Boc on the court, lent him the racket and played for him the role of a ball girl, provoking him to a „duel” with her father. Simona Halep even bowed to Mayor Boc (Burnar 2019a), to the thunderous ovations of 10,000 spectators. Conjecturally, it can be speculated that Boc earns political kudos from his association with Halep: the tennis player publicly expressed, on the same occasion, her gratitude to the mayor (in obvious contrast to her snubbing of Bucharest mayor Gabriela Firea on the National Arena see Conțescu, 2018) and her endorsement of a WTA tournament in Cluj, an event that would further increase the city's fame and, consequently, the already high approval rating of Mayor Boc (Monitorul, 2019b; Monitorul, 2019c).

\section{Gabriela Firea and the failed annexation in Bucharest}

What worked for Emil Boc and Cluj turned, however, spectacularly against another Romanian politician, namely Gabriela Firea, the general mayor of Bucharest between 2016 and 2020. She had her first contact with Halep in February 2018, when the politician awarded her with the title of honorary citizen at the Excelsior Theater (GSP, 2018a), "as a sign of recognition of sporting merits", as shown in an internal act of the Bucharest Municipality (CGMB, 2018). In June 2018, immediately after Halep won the final in Paris, the Bucharest Municipality was asked by the champion and her staff to organize a meeting with the fans, to present a replica of the trophy (GSP, 2018b). After recriminations that the Municipality marginalizes the event (DC News, 2018), the agreed place was the National Arena, the largest stadium in Romania (capacity: 55,634), and the date was set for June 11. In context, two days before, a Social Democratic Party (PSD) rally "against judicial abuses" had taken place in Bucharest, attended by about two hundred thousand supporters of the political party of which Gabriela Firea was a member (Hotnews, 2018a). She made a speech in front of the crowd, followed by the PSD leader, Liviu Dragnea, who opened his speech by urging people to congratulate Simona Halep because "she brought us joy after 40 years". PSD supporters present in Victoriei Square reacted with loud applause. 
Two days later, according to the press, "at the opening of the ceremony, the general mayor of Bucharest, Gabriela Firea (PSD)", wearing the tricolor scarf on her chest, "offered Simona Halep the symbolic key to the city and tried briefly to talk, but was booed off stage by the 20,000 people in the stands, who then chanted the sportswoman's name. Firea left the Arena before the end of the ceremony, at which point the boos turned even more intense" (Acum TV, 2018). As a result, "after this incident Gabriela Firea wrote on her Facebook page that the boos came from teams of hateful citizens, who came well organized, strategically placed among decent people" (Ştirile TVR, 2018). The mayor lamented that "no good deed goes unpunished" and accused "the Soros' propaganda apparatus" and "its press henchmen", "fake news", "malicious comments" or "money received from dubious NGOs to transform Bucharest into a city under siege. Faced with an avalanche of insults and other critical comments, which accused her of "using Simona's image for some political capital" (Vice, 2018) Firea had to shut down her Facebook page three times in just twenty hours (Newsweek, 2018).

But it was not only the appearance of Gabriela Firea next to Simona Halep and the fact that she preceded her in the order of speeches that infuriated people. After the ceremony,

a set of collages and videos designed in PSD laboratories, accredits the idea that tennis player Simona Halep, winner of the Roland Garros tournament, cheered on Sunday on the National Arena by tens of thousands of Bucharest residents, especially families with children, would have been, in fact, the booed one and not the general mayor of PSD Gabriela Firea (...). The materials, which would make Goebbels' propaganda apparatus envious, were conceived, as revealed by the former president of PSD Victor Ponta, by a certain George Harabagiu from Neamt, brought along at the PSD headquarters in Bucharest by Liviu Dragnea, president of PSD. The materials were disseminated by the PSD organizations Giurgiu, Mehedinți, Tulcea, Constanța, Bucharest, Ilfov, Vâlcea (...). He distributed at 20:01 the piece which was then taken over by many PSD county organizations, and wrote «Alert the organizations and dissemination groups in the counties. Maximize the impact of the posting. Divide into groups! » (Acum TV, 2018).

Harabagiu, the coordinator of PSD's online campaigns, was fired by the then PSD president, Liviu Dragnea, after the controversial campaign (Digi24, 2018), which outraged a good part of the Romanian media and public (Dobrescu, 2018). Through many of its members, PSD admitted that it had mismanaged the entire event, apologizing to Halep and its fans and eating humble pie for the "unforgivable blunder". "Simona Halep deserved neither the faking of the meaning of the Monday night festivity, nor the use of her name in an unintelligent manner. We have an obligation to apologize for this gesture. I personally do it", wrote the social democrat Ionut Vulpescu, former Minister of Culture, on his Facebook page (Eremia, 2018).

Mayor Firea also issued a mea culpa, following the wave of public criticism, stating after a few days that, based on her experience as a former journalist, she believed that "this is how it happens all over Europe, this is how it is done in America" (T, Topescu, 2018). 
In the Romanian media, the event was front page material for days in a row, generating a unanimously negative stance against the actions of the politician and condemning the political intrusion in sports (Dumitrescu, 2018). The general note was to qualify the appearance of the mayor next to Halep as a major blunder, a huge communication and political marketing error by the Municipality and especially by Firea personally. Covering the topic, Vice noted that "Simona Halep's victory at Roland Garros is about the only joy that the Romanian people still have today. Thus, it did not escape without being stained by the political dirt we are in" (Roşu, 2018).

Halep herself sought to distance herself from the scandal created around the moment, declaring: "I don't do politics, I don't say anything, I just went to share this joy of showing people the trophy. I went there strictly for the people, I do not want to comment on this topic" (Sport.ro, 2018).

Significant for our discussion is that what happened in Bucharest in June 2018 led the debate in another direction, some observers (Cartianu, 2019) wondering why a similar approach aimed at Halep, that of Mayor Emil Boc in Cluj (in the many cases previously described), worked in Transylvania, but failed dramatically for Gabriela Firea. The explanations can be neither categorical nor final, being rather a combination of factors: the public image of each of the mayors (generally good for Boc, seen as a progressive politician, in contrast to Firea, allegedly an impostor in politics), the political affiliation of each (an anti-PSD wave in Romanian society for the past five years being detrimental for the mayor of Bucharest), the positive promotion of Cluj in the mainstream press, unlike that of Bucharest, and so forth. A member of the National Audiovisual Council, Radu Herjeu, commented that the attitude of the press and public opinion in the case of Firea and Boc's association with Halep reeks of double standards and "propaganda": "Aha, I finally understood what propaganda wants to say! It's awful, even an electoral mess, to hand over the key of the capital city to the world number 1 in tennis, but it's a great and praiseworthy human refinement, totally apolitical on top, to go with the drum (!!!) to tennis matches and sneak in all the pictures with our players!" (DC News, 2019).

\section{Climbing up the political ladder: when Halep received the Presidential award}

The President of Romania, Klaus Iohannis, in turn awarded public honors to Halep, in July 2019, after she had won the Wimbledon tournament. As a result of her triumph, the sportswoman then received the highest decoration of the State: The National Order "Star of Romania" in the rank of Knight (Burnar 2019b). The ceremony was hosted by the Union Hall of the Cotroceni Palace, bordered by stained glass windows depicting the great historical figures of the Romanians, from Basarab I to Constantin Brâncoveanu. "Thank you on behalf of Romanians for the way you promote Romanian sport" the President told the tennis star (Digi 24, 2019), with the two also discussing the possibility of a match, which would have been televised. Halep would later countermand the match, "advised by relatives not to enter political games" (Conțescu, 2020). 
Interestingly, Simona Halep's political "annexation" came not only from politicians, but also, surprisingly, from fans. In August 2018, a fan of Halep from the diaspora took advantage of her presence at a match in Montreal to criticize, through an invective, the ruling party in Romania (PSD), being then imitated by other spectators (Dobrescu, 2018). In the end, Halep asked her fans to refrain from such actions (Chiujdea, 2018). A speculative explanation for choosing Simona Halep's match as an outlet for political frustrations, as a site of political protest, must take into account the high visibility of the event and the (self-) portrayal of the Romanian diaspora as a spokesman for the democratic aspirations of Romanians as a whole.

\section{The political use of Simona Halep as a vaccination vector during the COVID-19 outbreak}

Yet another instance in which Halep was used by Romanian politicians arised during the COVID-19 outbreak in 2020. At the start of the pandemic, when the situation was tense and Romanian authorities urged people to follow the health guidances they issued to curb the transmission of the virus, Halep was one of the celebrities who recorded a Public Service Announcement-type video message which was meant to inform about the risks of the pandemic, in March 2020 (GSP, 2020).

Subsequently, at the beginning of 2021, Halep was coopted by the Health Ministry of Romania to help the Romanian State in its propaganda effort to convince the general public of the effectiveness of the new vaccines that were just starting to be rolled out and administered against COVID-19. On January 5th, 2021, the Facebook page of the Ministry ran an image of Halep, containing a short quote: "Yes, I will surely take the vaccine jab", a photo which was accompanied by the caption:

Simona Halep is not only a sportswoman we admire, but also an example of responsibility to follow. After conquering COVID-19, Simona wants to get the vaccine, now she knows how the disease feels like.

"Yes, I will surely take the jab when possible, because I want this pandemic to end once and for all", Simona said. We all want it to end as soon as possible. To get back to the things and people we love. To our favourite sports. For that, we need to be responsible, to be like Simona. \#RoVACCINation (Ministerul Sănătății, 2021)

Although one can say that this is not an instance where a particular politician has taken credit for showing up next to Halep, we argue that this is another case of political instrumentalization, as the Romanian State is a political actor per se on the continental and the world stage, and on this occasion it plainly aimed to use Halep to inject life into a floundering vaccination effort (Onciu, 2021), which goes to show the sports hero's value for politics in this day and age, as his / her platform reaches millions of people, in some cases much more than a politician or a group of politicians will ever be able to. To put things into perspective, the Romanian elections of 6 December 2020 drew to the ballots only circa 6 million people (Rezultatevot.ro, 2020), less than one in three voters. It was the lowest turnout after the Romanian Revolution of 1989 (Prelipceanu, 2020), and it showed that Romanian people are disenchanted with politics, while 
Romanian politicians suffer from a lack of legitimacy. Hence, the use of sporting greats to endorse the contentious (at least, in the early stages) vaccination program.

\section{Conclusions}

As early as 2013, Simona Halep started to be appealing to Romanian politicians. The pioneer of Simona's public recognition was the mayor of Buşteni, the first mayor in Romania to award the Constanța native the diploma of honorary citizen, amid disinterest in Halep by other public authorities. From that moment on, alongside continuous improvements in the WTA rankings for Halep, the acts of homage coming from politicians began to multiply. Although the public honors practiced by officials towards a sports hero are commonly practiced worldwide, both the Romanian media and public have denounced in select cases the lack of legitimacy of certain initiatives, criticizing the said politicians as opportunists. In some cases, one can speak of a faulty application of an established communication strategy or a wrong judgment of the context by the organizers. Other politicians have not suffered the same fate, receiving preferential treatment from both Halep and the public and the media. This analysis, combining theories about the instrumentalization of sportspeople by politics with empirical research and the analysis of journalistic discourse, did not aim to provide definitive answers or issue verdicts on the legitimacy, morality or immorality of these public actions. Future studies have the mission to enrich our approach and to reveal the motivations of political actors in relation to the honored athletes.

\section{References}

Actualitatea de Călăraşi, (2018). Simona Halep a dansat pe ritmuri armâneşti, după ce a primit titlul de cetățean de onoare al municipiului Călăraşi. Actualitatea de Călăraşi [online]. 28 November 2018. [Viewed 14 January 2020]. Available from: https://actualitateacalarasi.eu/simona-halep-a-dansatpe-ritmuri-armanesti-dupa-ce-a-primit-titlul-de-cetatean-de-onoare-al-municipiului-calarasi/

Actualitatea Prahoveană, (2014). Recunoaştere: Simona Halep a primit un teren în Buşteni, în calitate de cetățean de onoare al oraşului. [online]. actualitateaprahoveana.ro. [Viewed 27 November 2019]. Available from: http://www.actualitateaprahoveana.ro/editia-electronica/actual/recunoasteresimona-halep-a-primit-un-teren-in-busteni-in-calitate-de-cetatean-de-onoare-al-orasului-11629

Acum TV, (2018). Gabriela Firea, primarul Bucureștiului (PSD), a fost huiduită la o ceremonie în onoarea Simonei Halep. Acum TV [online]. 13 June 2018. [Viewed 05 March 2020]. Available from: https://acum.tv/articol/81027/

Adevărul., (2013). Cartierul campionilor la Buşteni. Tenismena Simona Halep, cetățean de onoare al statiunii [online]. adevarul.ro. [Viewed 1 December 2019]. Available from: https://m.adevarul. ro/index.php/locale/ploiesti/tenismena-simona-halep-cetatean-onoare-orasului-busteni1_52a4a805c7b855ff568d20da/index.html

Adevărul., (2014). Halep, apreciată în toată România. Simona a fost recompensată de Primăria Buşteni pentru performanțele sale [online]. adevarul.ro. [Viewed 2 December 2019]. Available from: https://adevarul.ro/news/sport/halep-apreciata-romania-simona-fost-recompensata-primariabusteni-performantele-sale-1_530c6f64c7b855ff56a520d2/index.html

Afaae., (2019). Agnieszka Radwaska Will Not Be an Honorary Citizen Of Krakow. [online]. afaae.com. [Viewed 20 September 2019]. Available from: https://afaae.com/poland/agnieszka-radwaskawill-not-be-an-honorary-citizen-of-krakow-board-member-family-related-to-pis-politics/ 
24 The political annexation of the sports hero in contemporary Romania - Simona Halep

Agyepong, L., (2017). Understanding the concept of celebrity capital through an empirical study of the role of celebrity political endorsements in 2008 and 2012 Ghana election campaigns. VViewed 15 September 2019]. Available from: https://www.semanticscholar.org/paper/Understanding-theConcept-of-Celebrity-Capital-an-Agyepong/279f56790b43edaf980cd7a9c5069c8267c925be

Andrei, M., (2019). Emil Boc s-a dus în Cehia să le susțină pe Halep \& Co în meciul din Fed Cup VIDEO. Ştiri de Cluj [online]. 09 February 2019. [Viewed 30 January 2020]. Available from: https://www.stiridecluj.ro/sport/emil-boc-s-a-dus-in-cehia-sa-le-sustina-pe-halep-co-in-meciuldin-fed-cup-video

Antena 3, (2011). Emil Boc - sportiv, cântăreţ, muncitor, prim-ministru. Doar la popularitate mai are de recuperat. Antena 3 [online]. 31 July 2011. [Viewed 18 January 2020]. Available from: https://www.antena3.ro/politica/emil-boc-sportiv-cantaret-muncitor-prim-ministru-doar-lapopularitate-mai-are-de-recuperat-132271.html

Babos, T., (2018). Timi Became Honorary Citizen Of Budapest [online]. Babostimea.Hu. [Viewed 3 August 2019]. Available from: https://babostimea.hu/en/timi-became-honorary-citizen-ofbudapest/

Bădică, P., (2018). Firea şi-a reînchis pagina de FB a treia oară în 20 de ore. Newsweek [online]. 13 June. Updated 13 June 2018, 11:28. [Viewed 06 March 2020]. Available from: https:// newsweek.ro/politica/ firea-si-a-redeschis-pagina-de-facebook-dupa-ce-a-sters-miilecomentarii-negative

Barney, R.K. \& Barney, D.E. (1989). Night of herwes: Flags, flowers, and last hurricanes. Paper presented at the meeting of the North American Society for Sports History, Clemson, SC in Wenner, L.A. (ed.), Mediasport, Routledge, London, 1998, p. 138.

Becker, S. W., \& Eagly, A. H. (2004). The heroism of women and men. American Psychologist, 59(3), 163178. [Viewed 20 June 2019]. Available from: https://doi.org/10.1037/0003-066x.59.3.163

BeSoccer., (2019). Lahm Elected Honorary Citizen Of Munich [online]. BeSoccer. [Viewed 25 June 2019]. Available from: https://www.besoccer.com/new/lahm-elected-honorary-citizen-ofmunich-572543

Bocai, M., (2018). Simona Halep a dansat la Călăraşi şi pe ritmurile melodiei închinate ei (video). Ziua de Constanța [online]. 30 November 2018. [Viewed 14 January 2020]. Available from: https://www.ziuaconstanta.ro/stiri/monden/o-fata-cu-har-ce-a-iesit-din-neamul-armanescsimona-halep-a-dansat-la-calarasi-si-pe-ritmurile-melodiei-inchinate-ei-video-677885.html

Burnar, V. T., (2019a). Video recording made during Sports Festival 2019. June 2019. Author's personal collection.

Burnar, V. T., (2019b). Per aspera ad astra: Simona e, oficial, Steaua României. Lead.ro [online]. 30 July. [Viewed 30 July 2019]. Available from: https://lead.ro/per-aspera-ad-astra-simona-e-oficialsteaua-romaniei/

Cartianu, G., (2019). Cheia şi toba. De ce e Firea huiduită şi Boc apreciat? Nu oricine e binevenit în preajma Simonei Halep!. Ziaristii.com [online]. 12 February 2019. [Viewed 01 April 2020]. Available from: https://ziaristii.com/cheia-si-toba-firea-huiduita-boc-apreciat-nu-oricine-ebinevenit-preajma-simonei-halep/

Cashmore, E. (2006). Celebrity / Culture, Routledge, New York.

CGMB, (2018). Hotărâre privind conferirea titlului de "Cetățean de onoare al Municipiului Bucureşti" sportivei Simona Halep [online]. Bucureşti: CGMB. [Viewed 03 March 2020]. Available from: https://api.pmb.ro/storage/CetateniOnoare/H497_17.pdf

Chiujdea, S., (2018). Reacția lui HALEP, după ce mai mulţi români au strigat M..E PSD în timpul FINALEI de la Montreal. Arbitrul a cerut LINIŞTE. Gândul.ro [online]. 13 August. Updated 25 March 2019, 18:41. [Viewed 17 April 2019]. Available from: https://www.gandul.ro/ stiri/reactia-lui-halep-dupa-ce-mai-multi-romani-au-strigat-me-psd-in-timpul-finalei-de-lamontreal-arbitrul-a-cerut-liniste-17413264 
Coman, M. (2010). Vedete, Eroi şi Celebrități. Dilema Veche [online]. December 2010. [Viewed 15 July 2019]. Available from: https://dilemaveche.ro/sectiune/tema-saptamanii/articol/vedete-eroi-sicelebritati

Combs, J. E. (1984). Polpop: Politics and Popular Culture in America. Bowling Green University Popular Press, Ohio.

Conțescu, (2018). Simona Halep n-a vrut să iasă de mână cu Gabriela Firea. Culisele evenimentului de pe „Arena Naţională”. Libertatea [online]. June 2018. [Viewed 25 February 2020]. Available from: https://www.libertatea.ro/sport/simona-halep-n-a-vrut-sa-iasa-de-mana-cu-gabriela-firea2290862

Conțescu, D., (2020). De ce nu s-a mai disputat meciul demonstrativ de tenis dintre Simona Halep şi preşedinte. ”Nu i-a mai răspuns la telefon lui Iohannis!". Jocul urma să fie transmis de TVR. Libertatea [online]. 11 January. [Viewed 20 January 2020]. Available from: https://www.libertatea.ro/sport/simona-halep-klaus-iohannis-meci-amical-amanat-2839948

Croatia Open., (n.d.). Tournament History [online]. croatiaopen.hr. [Viewed 1 August 2019]. Available from: https://www.croatiaopen.hr/en/tournament/tournament-history/

Dawn., (2014). Nadal Named Adopted Son Of Madrid [online]. dawn.com. [Viewed 1 August 2019]. Available from: https://www.dawn.com/news/1104360

DC News, (2018). Simona Halep, motiv de scandal între Gabriela Firea şi Nicuşor Dan. DC News [online]. 11 June 2018. [Viewed 03 March 2020]. Available from: https://www.dcnews.ro/ simona-halep-motiv-de-scandal-intre-gabriela-firea-i-nicu-or-dan_596058.html

— (2019). Radu Herjeu, comparație între Firea şi Boc: În sfârşit am priceput şi eu. DC News [online]. 11 February. [Viewed 13 March 2020]. Available from: https://www.dcnews.ro/raduherjeu-comparatie-intre-firea-si-boc-in-sfarsit-am-priceput-si-eu_636561.html

Digi 24, (2014). Simona Halep, premiată în lipsă. Sportiva a primit titlul de onoare, cheia oraşului şi un teren [online]. digi24.ro. [Viewed 3 January 2020]. Available from: https://www.digi24.ro/ regional/digi24-constanta/simona-halep-premiata-in-lipsa-sportiva-a-primit-titlul-de-onoarecheia-orasului-si-un-teren-259990

_ (2018). Liviu Dragnea spune că l-a concediat pe George Harabagiu, presupusul autor al postărilor denigratoare despre Simona Halep [online]. digi24.ro. Updated 13 June 2018, 16:22. [Viewed 7 March 2020]. Available from: https://www.digi24.ro/stiri/actualitate/politica/liviu-dragneaspune-ca-l-a-concediat-george-harabagiu-presupusul-autor-al-postarilor-denigratoare-despresimona-halep-946592

- (2019). Simona Halep, decorată de Klaus Iohannis: „A fost mai mult decât un meci, a fost o lecție de concentrare, de forţă fizică şi psihică”. Digi 24 [online]. 30 July. [Viewed 30 July 2019]. Available from: https://www.digi24.ro/stiri/sport/tenis/simona-halep-decorata-de-klausiohannis-a-fost-mai-mult-decat-un-meci-a-fost-o-lectie-de-concentrare-de-forta-fizica-si-psihica1166710

DigisportRo., (2019). FCSB şi Simona Halep, cele mai populare branduri sportive româneşti pe Facebook. Cum arată Top 5 [online]. DigisportRo. [Viewed 10 October 2019]. Available from: https://www.digisport.ro/special/fcsb-si-simona-halep-cele-mai-populare-branduri-sportiveromanesti-pe-facebook-cum-arata-top-5-603554

Dinu, R., (2019). VIDEO „Ultrasul” Emil Boc, interviu în exclusivitate pentru GSP.ro după show-ul de la Fed Cup: „Toţi românii au de învăţat de la Simona Halep!” »Cum a descris meciul cu Garcia + ce l-a uimit la Rouen. Gazeta Sporturilor [online]. 23 April 2019. [Viewed 03 February 2020]. Available from: https://www.gsp.ro/sporturi/tenis/video-ultrasul-emil-boc-interviu-inexclusivitate-pentru-gsp-ro-dupa-show-ul-de-la-fed-cup-toti-romanii-au-de-appratat-de-la-simonahalep-cum-a-descris-match-cu-garcia-ce-la-uimit-la-rouen-565548.html

Dobrescu, P., (2018). Din tribune s-a strigat "M..e PSD!" în timpul meciului Simonei Halep cu Sloane Stephens! Cine e "vinovatul". Libertatea [online]. 12 August. Updated 13 August 2018, 08:02. 
26 The political annexation of the sports hero in contemporary Romania - Simona Halep

[Viewed 23 June 2019]. Available from: https://www.libertatea.ro/stiri/din-tribune-s-strigat-me-psd-timpul-meciului-simonei-halep-cu-sloane-stephens-cine-e-vinovatul-2361718

Dobrescu, P., (2018). Revoltător! Mai multe filiale PSD susțin că Simona Halep a fost cea huiduită, nu Gabriela Firea!. Libertatea [online]. 12 June. Updated 13 June 2018, 08:35. [Viewed 10 March 2020]. Available from: https://www.libertatea.ro/sport/revoltator-mai-multe-filiale-psd-sustinca-simona-halep-a-fost-cea-huiduita-2291439

Driessens, O. (2013). The celebritization of society and culture: Understanding the structural dynamics of celebrity culture. International Journal of Cultural Studies, 16(6), 641-657.

Dumitrescu, V., (2018). Aşa se întâmplă când amesteci sportul cu politica! Gabriela Firea, huiduită pe Arena Națională, după ce a urcat pe scenă alături de Simona Halep. VIDEO. DePrahova.ro [online]. 12 June. [Viewed 17 March 2020]. Available from: https://deprahova.ro/ national/2655-asa-se-intampla-cand-amesteci-sportul-cu-politica-gabriela-firea-huiduita-pearena-nationala-dupa-ce-a-urcat-pe-scena-alaturi-de-simona-halep-video.html

Dumitriu, D. L. (2018). Media construction of sport celebrities as national heroes. Revista Română de Comunicare și Relații Publice, 20(2), 21-33.

Eremia, R., (2018). PSD îşi pune cenuşă-n cap după gafa cu Halep. Adevărul [online]. 14 June. [Viewed 12 March 2020]. Available from: https://adevarul.ro/news/politica/psd-isi-pune-cenusa-n-capgafa-halep-1_5b22886ddf52022f7526096e/index.html

ExpressPress., (2015, October 22). Simona Halep e cea mai simpatica si populara din Romania! [online]. ExpressPress. [Viewed June 10 2019]. Available from: http://www.expresspress.ro/ simona-halep-e-cea-mai-simpatica-si-populara-din-romania/

Fanatik., (2017). Simona Halep, primită cu onoruri la Buşteni. De cine a fost însoțită [online]. fanatik.ro. [Viewed 20 December 2019]. Available from: https://www.fanatik.ro/foto-simona-halepprimita-cu-onoruri-la-busteni-de-cine-fost-insotita-17306973

— (2018). Simona Halep a fost numită cetățean de onoare al oraşului Călăraşi! Cum a fost primită! Video [online]. fanatik.ro. [Viewed 10 January 2020]. Available from: https://www.fanatik.ro/ simona-halep-a-fost-numita-cetatean-de-onoare-al-orasului-calarasi-cum-a-fost-primita-video18682317

Fishwick, M. W. (1975). American Heroes: Myth and Reality. Greenwood Press.

Focus on Travel News., (2018, August 8). Insider's Guide To Riga Stars Tennis Prodigy Jelena Ostapenko. [online] ftnnews.com. [Viewed 15 September 2019] Available from: https://ftnnews.com/other-news/34737-insider-s-guide-to-riga-stars-tennis-prodigy-jelenaostapenko

GSP, (2011, July 10). Elena Udrea Explică Huiduielile Primite La Gala Lui Bute. [online]. GSP. [Viewed 10 June 2019]. Available from: https://www.gsp.ro/sporturi/box/elena-udrea-explicahuiduielile-primite-la-gala-lui-bute-247012.html

(2014a). Simona Halep va primi titlul de cetățean de onoare al Constanței. [online]. GSP. [Viewed 27 November 2019]. Available from: https://www.gsp.ro/sporturi/tenis/simona-halep-vaprimi-titlul-de-cetatean-de-onoare-al-constantei-427818.html

(2014b). Analiză. Simona Halep a avut un an de poveste în 2013 » 70 de meciuri, 53 de victorii, 6 trofee. [online]. GSP. [Viewed 28 November 2019]. Available from: https://www.gsp.ro/ sporturi/tenis/analiza-simona-halep-a-avut-un-an-de-poveste-in-2013-70-de-meciuri-53-devictorii-6-trofee-412587.html

(2018a). SIMONA HALEP. FOTO Noul lider din WTA, premiat de Gabriela Firea » Simona Halep, declarată cetățean de onoare al Capitalei. Gazeta Sporturilor [online]. 26 February 2018. [Viewed 03 March 2020]. Available from: https://www.gsp.ro/sporturi/tenis/simona-halepfoto-noul-lider-din-wta-premiat-de-gabriela-firea-simona-halep-declarata-cetatean-de-onoare-alcapitalei-533785.html 
(2018b). UPDATE Halep le prezintă românilor trofeul astăzi în fața Arenei Naționale! Decizie ciudată a PMB: eveniment în afara stadionului. Ce a cerut Simona, ce i-a oferit Firea. Gazeta Sporturilor [online]. 11 June 2018. [Viewed 05 March 2020]. Available from: https://www.gsp.ro/sporturi/tenis/update-halep-le-prezinta-romanilor-trofeul-astazi-in-fataarenei-nationale-decizie-ciudata-a-pmb-eveniment-in-afara-stadionului-ce-a-cerut-simona-ce-i-aoferit-firea-541534.html

- (2019a). Emil Boc, răspuns pentru Ion Țiriac: „Suntem singurul oraş care poate oferi asta”. Gazeta Sporturilor [online]. 25 April 2019. [Viewed 10 February 2020]. Available from: https://www.gsp.ro/sporturi/tenis/emil-boc-raspuns-pentru-ion-tiriac-suntem-singurul-orascare-poate-oferi-asta-565699.html

— (2019b). Dezastru pentru Ilie Năstase şi Anghel Iordănescu la Europarlamentare: votanții lor intră pe Arena Națională. [online]. GSP. [Viewed 25 November 2019]. Available from: https://www.gsp.ro/gsp-special/diverse/alegeri-europarlamentare-ilie-nastase-si-angheliordanescu-rezultate-umilitoare-semne-de-intrebare-la-rapid-si- turris-568154.html

— (2020). VIDEO Simona Halep şi Camelia Potec, mesaj pentru români în plină pandemie de coronavirus: „Sunt doar un om, ca şi tine. Nu am mai trecut prin asta niciodată”. Gazeta Sporturilor [online]. 31 March. [Viewed 31 March 2020]. Available from: https://www.gsp.ro/ gsp-special/stiri-extrasport/simona-halep-si-camelia-potec-vedete-intr-un-clip-pentru-romani-intimpul-pandemiei-de-coronavirus-594557.html

Hoberman, J. M. (1977). Sport and political ideology. Joumal of Sport and Social Issues, 1(2), 80-114.

Hook, S., (1945). The Hero In History. Secker \& Warburg.

Hotnews, (2018a). PSD a strâns în Piața Victoriei peste 180.000 de manifestanți / Dragnea: Dacă nu vor înțelege că regimul lor s-a sfârşit, vom veni din nou, mai mulți, şi nu vom mai pleca / Mitingul s-a încheiat puțin după ora 22,00, piața s-a golit rapid. Hotnews [online]. 9 June 2018. [Viewed 03 March 2020]. Available from: https://www.hotnews.ro/stiri-esential-22498515fotogalerie-primele-grupuri-sus-tori-psd-ajuns-pia-victoriei-guvernul-acoperit-uria-steagtricolor.htm

(2018b). Sentință Definitivă în Dosarul Gala Bute: Elena Udrea, șase Ani De închisoare Cu Executare / Rudel Obreja, Cinci Ani De închisoare. [online]. HotNewsRo. [Viewed 10 June 2019]. Available from: https://www.hotnews.ro/stiri-esential-22490231-dosarul-gala-bute-rudelobreja-cinci-ani-nchisoare-elena-udrea-ase-ani-nchisoare-excutare-sentin-definitiv.htm

Houlihan, B., (2007). Politics and Sport. In: Ritzer, G. (Ed.): The Blackwell Encyclopedia of Sociology. Malden, MA: Blackwell Publishing, p. 3473.

IICRR., (2018). George Weah: From national hero to leader of the nation [online]. iicrr.ie. [Viewed 21 November 2019]. Available from: https://iicrr.ie/george-weah-national-hero-leader-nation/

IloveBusteni., (2014). Simona Halep, de Dragobete la Buşteni [online]. [Viewed 1 December 2019]. Available from: http://www.ilovebusteni.ro/evenimente/15-SIMONA_HALEP_DE_DRAGOBETE_LA_BU\% $\%$ C8\%98TENI/

Jurnalul de Calarasi, (2018).Cel puțin o motivație - STRĂBUNICII SIMONEI HALEP AU FOST LA CĂLĂRAŞI!. Jurnalul de Calarasi [online]. 23 November 2018. [Viewed 13 January 2020]. Available from: http://www.soridapress.ro/cel-putin-o-motivatie-strabunicii-simonei-halep-aufost-la-calarasi/

Jurnalul Prahovean., (2014a). Mesaj inedit pentru Simona Halep la Buşteni [online]. jurnalulph.ro. [Viewed 4 December 2019]. Available from: https://jurnalulph.ro/sport/9679-mesaj-ineditpentru-simona-halep-la-busteni.html

(2014b). Simona Halep, de Dragobete la Buşteni [online]. jurnalulph.ro. [Viewed 1 December 2019]. Available from: https://jurnalulph.ro/sport/6624-simona-halep-de-dragobete-labusteni.html

Klapp, O. E. (1949). Hero worship in America. American Sociological Review, 14(1), 53-62. 
28 The political annexation of the sports hero in contemporary Romania - Simona Halep

La Stampa., (2017). Maradona Awarded Honorary Citizenship In Naples [online]. Lastampa.It. [Viewed 24 June 2019]. Available from: https://www.lastampa.it/2017/07/06/esteri/maradonaawarded-honorary-citizenship-in-naples-oxn1ZsxvorWsStok0WbihN/pagina.html

Libertatea., (2014). Simona Halep îşi face casă de vacanță la Buşteni! Vecinii ei: alți doi campioni! [online]. libertatea.ro. [Viewed 3 December 2019]. Available from: https://www.libertatea.ro/ sport/simona-halep-isi-face-casa-de-vacanta-la-busteni-vecinii-ei-alti-doi-campioni-992911

Libertatea., (2018). Radu Mazăre o umileşte de patru ani pe Simona Halep. Ce spunea fugarul în Madagascar, în martie 2014 [online]. libertatea.ro. [Viewed 1 December 2019]. Available from: https://www.libertatea.ro/sport/radu-mazare-o-umileste-de-patru-ani-pe-simona-halep2099179

Lin, C. Y., Lee, P. C., \& Nai, H. F. (2008). Theorizing the role of sport in state-politics. International Journal of Sport and Exercise Science, 1(1), 23-32.

Lines, G. (2001). Villains, fools or heroes? Sports stars as role models for young people. Leisure Studies, 20(4), 285-303. Available from: https://doi.org/10.1080/02614360110094661

Marsh, D., Hart, P. T., \& Tindall, K. (2010). Celebrity politics: The politics of the late modernity?. Political Studies Review, 8(3), 322-340.

Media9, (2019a). Galeria Simonei Halep s-a întors. O galerie de şefi :) FOTO. media9.ro [online]. February 2019. [Viewed 20 February 2020]. Available from: https://media9.ro/galeria-simoneihalep-s-a-intors-o-galerie-de-sefi-foto/

Media9, (2019b). Primăria bate toba. Galeria de şefi a Simonei Halep, gata de acțiune :). media9.ro [online]. April 2019. [Viewed 20 February 2020]. Available from: https://media9.ro/primariabate-toba-galeria-de-sefi-a-simonei-halep-gata-de-actiune/

Ministerul Sănătății., (2021). [Facebook]. 05 January. [Accessed 06 January 2021]. Available from: https://www.facebook.com/MinisterulSanatatii/posts/1346343982387030/

Monitorul, (2019a). Emil Boc va face deplasarea la Rouen pentru partida Franța - România din semifinalele Fed Cup, programată în week-end-ul următor, 20-21 aprilie. Monitorul de Cluj [online]. 16 April 2019. [Viewed 01 February 2020]. Available from: http://www.monitorulcj.ro/ sport/70511-emil-boc-sef-de-galerie-la-meciul-franta---romania-din-semifinalele-fed-cup

Monitorul, (2019b). De ce PNL nu a câştigat alegerile la Cluj, deşi Emil Boc are o cotă de încredere uriaşă. Monitorul de Cluj [online]. 4 June 2019. [Viewed 01 March 2020]. Available from: http://www.monitorulcj.ro/politica-administratie/71750-de-ce-pnl-nu-a-castigat-alegerile-la-clujnapoca-desi-emil-boc-are-o-cota-de-incredere-uriasa

Monitorul, (2019c). Boc, cel mai iubit primar... pe Facebook! Cifre zdrobitoare pentru edilul clujean. Monitorul de Cluj [online]. 5 June 2019. [Viewed 01 March 2020]. Available from: http://www.monitorulcj.ro/actualitate/71793-boc-cel-mai-iubit-dintre-primarii-de-provinciecifre-zdrobitoare-pentru-edilul-clujean

Niţu, C., (2018). Simona Halep la Călăraşi / Drăgulin: Este numărul 1 mondial! Halep: Sunt onorată să fiu la Călăraşi. Ediția.ro [online]. 29 November 2018. [Viewed 14 January 2020]. Available from: https://editia.ro/2018/11/29/simona-halep-la-calarasi-dragulin-este-numarul-1-mondial-halepsunt-onorata-sa-fiu-la-calarasi/

Norwood, D. R. (1982). The sport hero concept and Louis Cyr (p. 12), Master Thesis, Electronic Theses and Dissertations, viewed 20 June 2019. Available from: https://scholar.uwindsor.ca/ etd/4292

Novinite., (2014). Grigor Dimitrov Becomes Honorary Citizen Of Varna [online]. Novinite.com. [Viewed 25 June 2019]. Available from: https://www.novinite.com/articles/162132/ Grigor+Dimitrov+Becomes+Honorary+Citizen+of+Varna 
Observator de Călărași., (2018). Simona Halep a primit titlul de cetățean de onoare al municipiului Călăraşi [online]. observatorcl.info. [Viewed 10 January 2020]. Available from: https://observatorcl.info/simona-halep-a-primit-titlul-de-cetatean-de-onoare-al-municipiului-calarasi/

Observatorul Prahovean., (2017). Ştampilă specială a Poștei Române, dedicată Simonei Halep, folosită exclusiv la Buşteni [online]. observatorulph.ro. [Viewed 23 December 2019]. Available from: https://www.observatorulph.ro/viata-prahovei/88517-stampila-speciala-a-postei-romanededicata-simonei-halep-folosita-exclusiv-la-busteni

Onciu, A., (2021). Eşecul campaniei de vaccinare înseamnă continuarea pandemiei şi un dezastru economic greu de imaginat. Mediafax [online]. 03 January. [Viewed 04 January 2021]. Available from: https://www.mediafax.ro/editorialistii/comentariu-adrian-onciu-esecul-campanieide-vaccinare-inseamna-continuarea-pandemiei-si-un-dezastru-economic-greu-de-imaginat19848875

Orwell, G. (2000). Essays. Penguin Classics.

Paddick, R. (1984). Sport and Politics: The (Gross) Anatomy of Their Relationships. The Journal of the Australian Society for Sports History, 1(2), 51-66.

Pal, A., (2019). Halep a schițat „,portretul” victoriei entuziasmante cu Siniakova, la conferința de presă: „Publicul m-a ambiționat, mi-a dat energie!”. Cum l-a lăudat pe Emil Boc. ProSport [online]. 10 February 2019. [Viewed 24 January 2020]. Available from: https://www.prosport.ro/altesporturi/tenis/halep-a-schitat-portretul-victoriei-entuziasmante-cu-siniakova-la-conferinta-depresa-publicul-m-a-ambitionat-mi-a-dat-energie-cum-l-a-laudat-pe-emil-boc-17869777

Pedersen, P. (Ed.) (2013). Routledge Handbook of Sport Communication. Routledge, New York.

Pîrloagă, M., (2018). Tenismena constănțeană Simona Halep va primi titlul de călărăşean de onoare. Iată de ce... . Atitudinea din Călăraşi [online]. n.d. . [Viewed 17 January 2020]. Available from: https:/ / atitudineadincalarasi.ro/tenismena-constanteana-simona-halep-va-primi-titlul-decalarasean-de-onoare-iata-de-ce/

Popa, E.N., (2018). Emil Boc, reacție virală după îmbrățişarea cu Simona Halep. Fanatik [online]. 22 April 2018. [Viewed 17 January 2020]. Available from: https://www.fanatik.ro/emil-boc-reactievirala-dupa-imbratisarea-cu-simona-halep- 18330865

Prelipceanu, M., (2020). Parlamentare 2020: Prima analiză a rezultatelor scrutinului din 6 decembrie. rfi.ro [online]. 07 December. [Viewed 08 December 2020]. Available from: https://www.rfi.ro/ asculta-la-rfi-ro-128250-parlamentare-2020-prima-analiza-rezultatelor-scrutinului-din-6decembire

Prodan, M., (2015). Cum au ajuns să scrie de Cluj Reuters, BBC, The Guardian şi CNBC - în acelaşi timp. Actual de Cluj [online]. 25 iulie 2015. [Viewed 05 February 2020]. Available from: https://actualdecluj.ro/cum-au-ajuns-sa-scrie-de-cluj-reuters-bbc-the-guardian-si-cnbc-inacelasi-timp/

ProSport., (2018a). Cât a băut Traian Băsescu la celebra petrecere de la Golden Blitz, după sfertul UEFAntastic Steaua - Rapid. Rădoi: „Am stat toată seara lângă el!” [online]. prosport.ro. [Viewed 20 November 2020]. Available from: https://www.prosport.ro/fotbal-intern/cat-abaut-traian-basescu-la-celebra-petrecere-de-la-golden-blitz-dupa-sfertul-uefantastic-steaua-rapidradoi-am-stat-toata-seara-langa-el-17639162

— (2018b). După Bucureşti, Buşteni. Decizia luată de primarul stațiunii de pe Valea Prahovei în semn de reverență pentru triumful Simonei Halep de la Roland Garros [online]. prosport.ro. [Viewed 5 January 2020]. Available from: https://www.prosport.ro/alte-sporturi/tenis/dupabucuresti-busteni-decizia-luata-de-primarul-statiunii-de-pe-valea-prahovei-in-semn-de-reverentapentru-triumful-simonei-halep-de-la-roland-garros-17256116

Realitatea din Călăraşi, (2018). Sula...prefectura... Drăgulin... Biroul de presă şi Simona Halep!. Realitatea din Călăraşi [online]. 22 November 2018. [Viewed 13 January 2020]. Available from: 
30 The political annexation of the sports hero in contemporary Romania - Simona Halep

https://realitateadincalarasi.ro/2018/11/22/sula-prefectura-dragulin-biroul-de-presa-si-simonahalep/

Rein, R., (1998), "El primer deportista: the political use and abuse of sport in Peronist Argentina", The International Journal of the History of Sport, 15: 2, p. 54.

Rein, R. (1998). 'El primer deportista': the political use and abuse of sport in peronist Argentina. The International Journal of the History of Sport, 15(2), 54-76.

Republika News., (2017). Cetățenii de onoare fac cinste oraşului Buşteni! Mesajul senatorului Emanoil Savin pentru Simona Halep [online]. republikanews.ro. [Viewed 23 December 2019]. Available from: https://www.republikanews.ro/cetatenii-de-onoare-fac-cinste-orasului-busteni-mesajulsenatorului-emanoil-savin-pentru-simona-halep/

Rezultatevot.ro., (2020). Rezultatevot.ro [online]. [Viewed 01 February 2021]. Available from: https://rezultatevot.ro/elections/112/results

Roşu, I., (2018). Cum am trăit momentul în care Firea a fost huiduită că s-a folosit de Halep. Vice [online]. 12 June. [Viewed 06 March 2020]. Available from: https://www.vice.com/ ro/article/9k8gxz/momentul-in-care-firea-a-fost-huiduita-ca-sa-folosit-de-halep

Smart, B. (2005). The Sport Star: Modern Sport and the Cultural Economy of Sporting Celebrity. SAGE.

Smith, G. (1973). The Sport Hero: An Endangered Species. Quest, 19(1), 59-70.

Sport.ro, (2014). Cum a ajuns Simona Halep cetatean de onoare in Calarasi: "Stramosii ei au trecut pe aici!" :) Explicația primarului din oraşul FĂRĂ tenis. Sport.ro [online]. 28 November 2018. [Viewed 14 January 2020]. Available from: https://www.sport.ro/tenis/cum-a-ajuns-simonahalep-cetatean-de-onoare-in-calarasi-stramosii-ei-au-trecut-pe-aici-explicatia-primarului.html

(2018). "Eu nu fac politica!" Ce spune Simona Halep despre huiduielile primite de Firea pe Național Arena. Sport.ro [online]. 15 June 2018. [Viewed 20 March 2020]. Available from: https://www.sport.ro/tenis/eu-nu-fac-politica-ce-spune-simona-halep-despre-huiduielileprimite-de-firea-pe-national-arena.html

_ (2019). Adevăratul motiv pentru care Emil Boc a fost şef de galerie în Cehia! Planul pus la cale pentru 2020. Sport.ro [online]. 11 February 2019. [Viewed 20 February 2020]. Available from: https://www.sport.ro/tenis/adevaratul-motiv-pentru-care-emil-boc-a-fost-sef-de-galerie-incehia-planul-pus-la-cale-pentru-2020.html

Ştirile TVR, (2018). Gabriela Firea, huiduită pe Arena Națională. "Echipe de cetățeni cu venin au venit bine organizate, plasate strategic printre oameni decenți". stiri.tvr.ro [online]. 11 June, 22:38. Updated 11 June, 23:56. [Viewed 05 March 2020]. Available from: http://stiri.tvr.ro/gabrielafirea--huiduita-pe-arena-na--ionala----echipe-de-cetateni-cu-venin-au-venit-bine-organizate-plasate-strategic-printre-oameni-decenti_832344.html\#view

Ştiripesurse, (2019). "Strategia 'llie și Puiu' la UNPR: dezvăluiri din campania la europarlamentare" [online]. stiripesurse.ro [Viewed 22 November 2019]. Available from: https://www.stiripesurse.ro/strategiailie-i-puiu-la-unpr-dezvaluiri-din-campania-la-europarlamentare_1352698.html

The Guardian, (2018, June 23). Mohamed Salah ‘honoured' With Gift of Citizenship From Chechen Leader [online]. The Guardian. [Viewed 10 December 2019]. Available from: https://www.theguardian.com/football/2018/jun/23/mo-salah-egypt-liverpool-ramzankadyrov-chechnya-russia-world-cup

— (2018, September 10). 'A new heroine': Japan celebrates first grand slam winner amid Serena row [online]. The Guardian. [Viewed 20 August 2019]. Available from: https://www.theguardian. com/world/2018/sep/10/naomi-osaka-japan-ignores-serena-spat-to-celebrate-first-grand-slamwinner

The Portugal News., (n.d.). Luis Figo becomes honorary citizen of Faro [online]. The Portugal News. [Viewed 24 June 2019]. Available from: https://www.theportugalnews.com/news/luis-figobecomes-honorary-citizen-of-faro/16045 
Țopescu, C., (2018). Exclusivitate RFI: Gabriela Firea despre evenimentul de pe Arena Națională dedicat Simonei Halep -"Am greşit". rfi.ro [online]. 18 June. [Viewed 12 March 2020]. Available from: https://www.rfi.ro/social-104075-gabriela-firea-despre-evenimentul-arena-nationaladedicat-simona-halep

Turner, G., (2004). Understanding Celebrity. SAGE, London.

Ziare.com, (2019). Simona Halep si-a anuntat prezenta la Sports Festival. ziare.com [online]. 21 March 2019. [Viewed 25 February 2020]. Available from: https://ziare.com/simona-halep/stiri-simonahalep/simona-halep-si-a-anuntat-prezenta-la-sports-festival-1554458

Ziua de Constanta., (2014). Simona Halep are melodie lăutărească! [online]. [Viewed 3 December 2017]. Available from: https://www.youtube.com/watch?v=QIhzTOY0E1o 